\title{
Land Degradation and Preventive Measures from the Perspective of the Stakeholders
}

\author{
${ }^{1,4}$ Mosayeb Heshmati, ${ }^{1,3}$ Arifin Abdu, \\ ${ }^{1}$ Nik Muhamad Majid and ${ }^{2} \mathrm{~J}$. Shamshuddin \\ ${ }^{1}$ Department of Forest Production, Faculty of Forestry, \\ ${ }^{2}$ Department of Land Management, Faculty of Agriculture, \\ ${ }^{3}$ Institute of Tropical Forestry and Forest Products, \\ University Putra Malaysia, 43400 UPM Serdang, Selangor, Malaysia \\ ${ }^{4}$ Department of Watershed Management, Agriculture and Natural Research Center, Kermanshah, Iran
}

Received 2011-03-22, Revised 2013-07-17; Accepted 2013-08-19

\begin{abstract}
Land degradation at the catchment scale in Iran is widespread, usually assumed to be accelerated by the activities of local inhabitants. Social issues such as low income, poverty and low level of welfare and education contribute to land degradation. A study was conducted to identify the causes of land degradation in Merek catchment, Iran and to propose appropriate measures to curtail it. In this study, land/soil surveys were carried out and soil samples analyzed. Subsequently, farmers, herders and nomads were interviewed and relevant experts were consulted. The results revealed that improper tillage practices, overgrazing and forest clearance were the worst significant human-induced factors causing land degradation. The other factors include crop cultivation without rotation and fallow period, improper tillage practices, crop residues burning and conversion of rangelands and forest to agricultural areas. Training and extension, soil conservation measures with farmers' participation, enactment of new laws and amending of current laws (for monitoring agricultural activities such as fertilizers and pesticide application and burning of crop residues), forest preservation, improving the current grazing systems and empowering government employees are the possible measures to curtail land degradation in the study area. It is suggested that the government should create job opportunities among the unemployed in the village and enhance their welfare by introducing insurance, health services and educational level. These measures would result in sustainable agricultural practices in the Merek catchment and help ensure conservation of its rangeland and forest.
\end{abstract}

Keywords: Land Degradation, Local Inhabitant, Relevant Expert, Merek Catchment, Terminology, Karkheh River Basin (KRB), Soil Nutrient Contents (NPK), Erosion Intensity, Nutrient Depletion, Soil Organic Carbon (SOC)

\section{INTRODUCTION}

It is believed that land degradation at the catchment scale is accelerated by the action of the local people. Social issues such as low income, poverty and low level of welfare and education help promote land degradation through improper land use activities. Local communities (as the major stakeholders) play an important role in the occurrence or absence of land degradation (Farshad and Barrera-Bassols, 2003). Land degradation is a serious matter in the upper catchment of the semi-arid regions of Iran. In these areas, the major causes of land degradation are conversion of rangelands to agricultural areas, improper plowing and irrigation, overgrazing, poor vegetation cover and extensive livestock; all these result in sudden change in agro-ecological environment and biological diversity (Ashrafi, 2003; Glavovic et al., 2002). Consequently,

Corresponding Author: Arifin Abdu, Department of Forest Production, Faculty of Forestry, University Putra Malaysia, 43400 UPM Serdang, Selangor, Malaysia Tel: +60389467177 Fax: +60389432514 
food and environmental security in the affected regions are compromised or at stake (Turkelboom, 2003).

In Iran, improper tillage practice is rampant. Use of heavy agricultural machinery in autumn, followed by sowing before rainfall has resulted in serious soil erosion. The study of Bechmann et al. (2009) revealed that this kind of tillage practice caused three-fold erosion in the upper catchment of Norway. In this area, smallholders adopt unsuitable land leveling technique that result in serious land degradation. In Cameron Highlands, Malaysia, Hashim and Abdullah (2005) showed that frequent plowing and land shaping led to soil erosion and nutrient losses. Crop residues burning for continued cultivation without fallow and rotation periods is another improper agricultural activity in the semi-arid regions. In Iran, it is estimated that crop residues burning had resulted in the emission of 259 and $10 \mathrm{Gg}$ of $\mathrm{CO}_{2}$ and $\mathrm{NO}_{2}$, respectively (IRI, 2003).

Rangeland is also suffering from destruction via early grazing, overgrazing and conversion to agricultural lands which happen because of increased number of grazing livestock. Shahmoradi et al. (2008) estimated that there were 9.4 million animal units of grazing animals in the rangelands and forests in the upper Karkheh Basin, which is part of the study area. In most parts of Iran, overgrazing is carried out by rural inhabitants and nomads. About 46 million animal units exist above the carrying capacity of the rangelands in Iran over the past 30 years, resulting in losses of 110 million $\mathrm{kg}$ of dry forage (WB, 2005). The condition of forest is even worse than that of the rangeland. We know that from 1944-2000, forest area was reduced from 19.5-12.4 million ha.

All the issues related to human-induced land degradation should be subjected to Integrated Catchment Management (ICM) for human welfare so as to sustain the protection of the natural resources of an area (Brunis and Heberling, 2004). In addition, solving of the problems, having specific goals and local community consensus are the three keys to successful implementation of any project (Heathcote, 1998). The public and private sectors should undertake proactive and reactive approaches to soil conservation (Debarry, 2004). Due to lack of coordination in the conservation program, land degradation is accelerated in Iran. As such, participation of stakeholders in protecting natural resources is limited. The objectives of this study were: (i) to determine the perception of local community and relevant experts about land degradation in the Merek catchment, Iran; and (ii) to propose appropriate measures to curtail land degradation in the area.

\section{MATERIALS AND METHODS}

\subsection{Definition of the Terminology Used}

The two important terminologies namely land degradation and stakeholders as used in this study are defined as:

- Land degradation is the human-induced (or via natural means) deterioration of soil/land quality and productivity in a particular area of concern

- Stakeholders are the local inhabitants (farmers, herders and nomads in Merek catchment, Iran) and relevant experts (in agriculture, soil, forest, rangeland and watershed management, extension and agronomy)

\subsection{Description of Study Area}

This study was conducted at the Merek catchment, located about $35 \mathrm{~km}$ southeast of Kermanshah, Iran. It is an upper catchment of the Karkheh River Basin (KRB) in Zagros Mountain Chains (34 00' 38"-34 09'31" N; $47^{\circ} 04^{\prime} 25^{\prime \prime}-\mathrm{d} 47^{\circ} 22^{\prime} 18^{\prime \prime}$ E) (Fig. 1). The total area is about 23,038 ha, with 14810 ha for agriculture, 6632 ha for rangeland and 11596 ha for forest. The average annual precipitation and temperature is $504 \mathrm{~mm}$ and $19.4^{\circ} \mathrm{C}$, respectively. Forty three villages with about 7500 inhabitants are found in this catchment. The main types of their livelihood are livestock production and farming activities. In this area, winter wheat, barley, chickpea, sugar beet and maize are the crops grown, whereas sheep rearing is the main livestock. The population of grazed animal is 44850 herds, including 31400 sheep and lamb, 8550 goat and 4900 cattle. The rangeland capacity is only 7500 animal unit and therefore the area is overgrazed.

\subsection{Geomorphological Facies and Soil Properties}

A map of the geomorphological facies was prepared using geology, topography (slope steepness, elevation), erosion features and land use as well as satellite image (land-sat 2002) and GIS software (Ilwis version 3.5) (Fig. 2). Soil sampling and field verification were carried out within each geomorphological facies. Soil analyses done were soil texture, aggregate stability, $\mathrm{pH}$, organic carbon and Soil Nutrient Contents (NPK) using standard methods. The statistical analyses of the data obtained from this study were carried out by SAS version 6.12 . Soil erosion intensity was estimated in each geomorphological facies within agro-ecological zones (agriculture, rangeland and forest) using Pacific Southwest Inter-Agency Committee (PSIAC) model. 


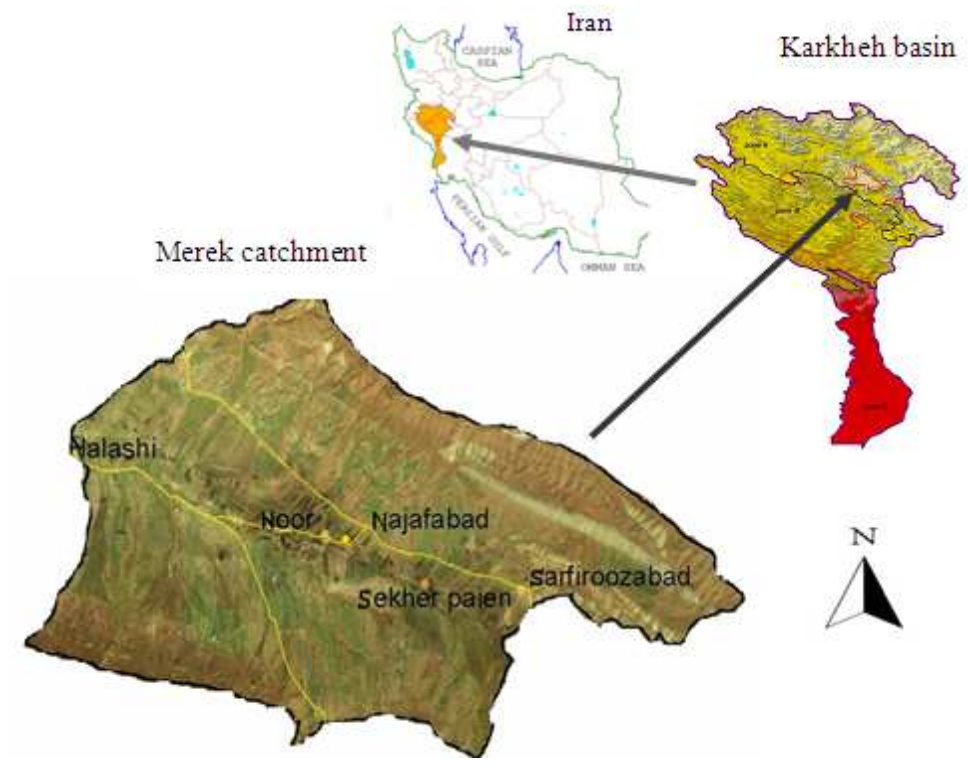

Fig. 1. A map showing the location of the Merek catchment

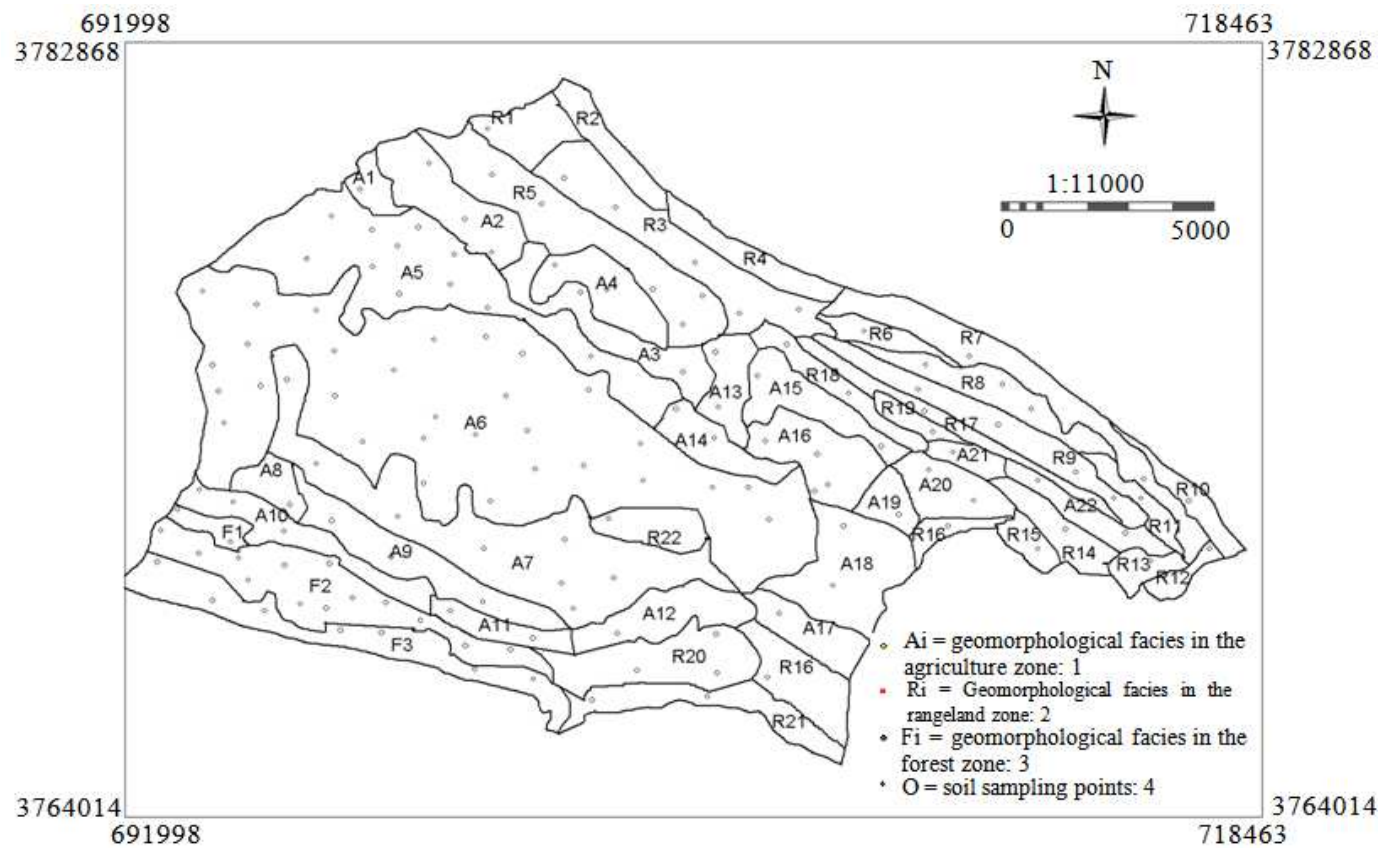

Fig. 2. Distribution of geomorphological facies in the Merek catchment

\subsection{Interviewing Local Inhabitants}

Eighty two respondents (farmers, herders and nomads) in the Merek catchment were interviewed by the use of questionnaire (Table 1) in order to determine what they thought about the causes and possible solutions to land degradation. The interview was based on the following premise:

- The need and justification of the interview were explained to the local councils and leaders 
- The questions in the questionnaire were translated into local dialects

- The causes of land degradation and possible solutions were prioritized based on suggestions of the respondents

\subsection{Interviewing Relevant Experts}

Human-induced causes of land degradation in the Merek catchment and its possible solutions were discussed in a meeting with at least 74 relevant experts with 15 years experience in dealing with land degradation and land use policy. The discussion with each expert was based on the criteria given in Table 2. Human-induced factors of land degradation in the Merek catchment and its possible solutions were prioritized based on their experiences and suggestions. The experts were in the field of soil science, watershed management, rangeland management, forestry, extension and agronomy.

Table 1. The questionnaire for interviewing local habitants

\begin{tabular}{ll}
\hline $\begin{array}{l}\text { Village: } \\
\text { Tel: }\end{array}$ & $\begin{array}{l}\text { Date: Respondent name: } \\
\text { Gender: male female }\end{array}$ \\
\hline Part 1: Common information & \\
Education: & The sources of Knowledge about Soil: \\
1. Illiterate & 1. Extension Training course \\
2. Primary school & 2. Workshop \\
3. High school & 3. Visit of other areas \\
4. Diploma & 4. Communications tools (radio, TV, newspaper) \\
5. University & 5. Own experience \\
& 6. Indigenous knowledge
\end{tabular}

Part 2: Land degradation and its solution in local people opinion 2.1. Why is soil important to you?
1. For my livestock
2. For wildlife
4. Water storage
5. Crop production
3. Industry (brick, cement)
6. Others (please specify)

2.2. In your area, which of the following issues are the most important causes of land degradation?
1. Over grazing
2. Conversion of rangeland to cultivated lands
3. Improper tillage practices (up to down the hillside)
4. Deforestation
5. Mining
6. Cultivation without rotation and fallow
7. The crops residual burning
8. Improper road construction

2.3. In your opinion, which of the following measures is the possible solution for land degradation in your area?

1. Rangeland protection by government intervention

2. Forest protection by government intervention

3. Control of the overgrazing with participatory of the local people

4. Rangeland rehabilitation by seeding

5. Controlling the crops residual burning (by penalty or levy taxes)

6. Controlling improper tillage operations (by penalty or levy)

7. Training and extension

8. Optimizing chemical fertilizers and pesticides using
9. Nomads steeling in the forest
10. Fire making on rangeland and forest
11. Industrial activities
12. Flooding
13. Over application of chemical fertilizers and pesticides
14. Waste disposal
15. Others (please specify)

Remaras:
9. Mechanical methods measurement (earth dam, check dam, terracing
10. Strip cropping in the rain-fed area
11. Orchard and tree planting on sloping lands
12. Forage cultivation on steep slops lands
13. Fallow and rotation period
14. Fire control in border of forest and rangeland (by penalty)
15. Others (please specify)


Table 2. Important human-induced factors of land degradation and possible solutions

\begin{tabular}{|c|c|c|}
\hline Code & Factor & $\begin{array}{l}\text { Ranked by } \\
\text { relevant experts }\end{array}$ \\
\hline 1 & Overgrazing & \\
\hline 2 & Improper tillage practices (up to down the hill slope) & \\
\hline 3 & Conversion of rangeland to cultivated land & \\
\hline 4 & Conversion of the forest to cultivated land & \\
\hline 5 & Improper mining activates & \\
\hline 6 & Fire making in the forest and rangeland & \\
\hline 7 & Root out or drying of forest trees using herbicide & \\
\hline 8 & Branch cutting of the trees in the forest & \\
\hline 9 & Conversion of the wetland and border of stream to agricultur & \\
\hline 10 & Improper road construction & \\
\hline 11 & Temporary settlement of nomads in the forest & \\
\hline 12 & Over using of chemical fertilizers, pesticide and herbicide & \\
\hline 13 & Cultivation practices without rotation and fallow periods & \\
\hline 14 & $\begin{array}{l}\text { Improper land leveling and changing the drainage } \\
\text { system using heavy machinery (bulldozers, ... ) }\end{array}$ & \\
\hline 15 & Burning the crops residues & \\
\hline 16 & Lobby groups & \\
\hline 17 & Current low and relative official statues & \\
\hline 18 & Conflicts & \\
\hline 19 & Poverty, low income & \\
\hline 20 & Other (please specify) & \\
\hline
\end{tabular}

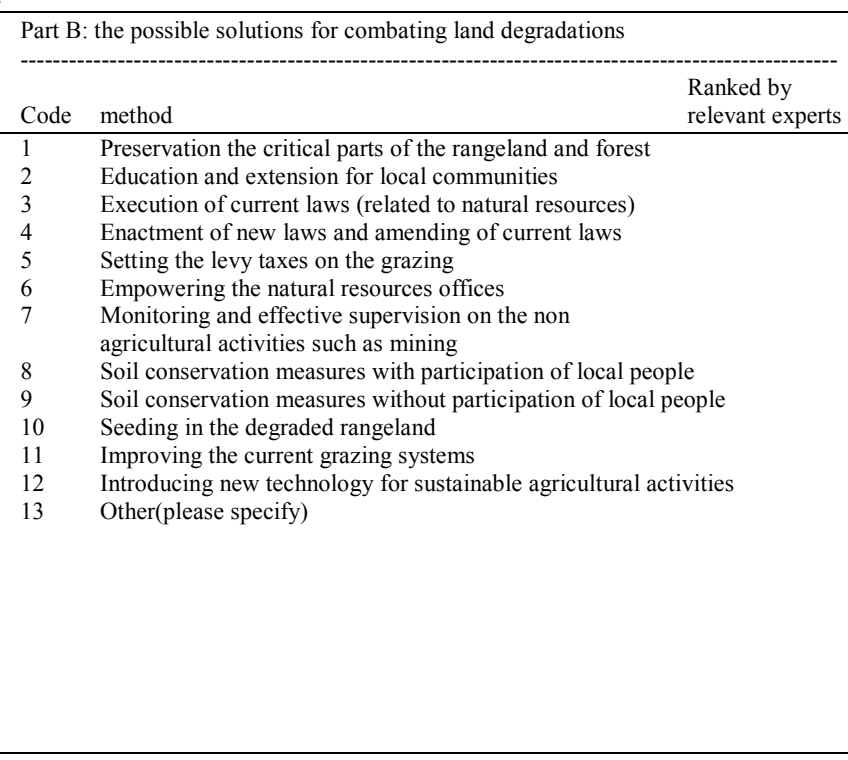

\section{RESULTS AND DISCUSSION}

\subsection{Soil Properties, Nutrient Level and Erosion Intensity}

\subsubsection{Soil Properties and Nutrient Level}

Results of the soil analyses showed that the soils were mainly of heavy texture (clayey), containing an average of 43,37 and $22 \%$ of clay, silt and sand, respectively. The respective aggregate stability of the soils was 54, 61 and $64 \%$ for the agriculture, rangeland and forest zone. The soils reaction were moderately alkaline ( $\mathrm{pH}$ was about 7.5) and there was no significant difference of soil $\mathrm{pH}$ among the zone, probably due to high carbonate content (33-40\%). Soil organic carbon decreased with soil depth and is different among the agro-ecological zones. The value was 1.4, 1.6 and $2.2 \%$ in the topsoil of agriculture area, rangeland and forest respectively; organic carbon in the soils of the agriculture was significantly lower than that of the other zones. The average $\mathrm{N}$ in the agriculture area, rangeland and forest was $0.14,0.17$ and $0.18 \%$, respectively. Likewise, the value of $\mathrm{N}$ in the agriculture area was significantly lower than that of the other areas. The mean available $\mathrm{P}$ in the agriculture area, rangeland and forest was $15.1,14.6$ and $12.3 \mathrm{mg} \mathrm{kg}^{-1}$, respectively; however, the value of $P$ in the soils of the forest was significantly lower than that of the other zones. Taking chemical properties into consideration, the soils in the Merek catchment are degraded.

\subsection{Erosion Intensity and Nutrient Depletion}

This catchment is suffering from different erosion features such as gully, rill and inter-rill. The erosion rate in the agriculture area, rangeland and forest was 14.5, 16.6 and $18.6 \mathrm{t} \mathrm{ha}^{-1}$ year $^{-1}$, respectively. The predicted respective annual N, P and K depletion by erosion was 27.6, 0.247 and $6.54 \mathrm{~kg} \mathrm{ha}^{-1}$ year $^{-1}$ in agriculture, rangeland and forest zone. The highest loss in Soil Organic Carbon (SOC) was in the forest with a value of $414 \mathrm{~kg} \mathrm{ha}^{-1} \mathrm{year}^{-1}$, while the lowest was in the agriculture area with a value of $213 \mathrm{~kg} \mathrm{ha}^{-1}$ year $^{-1}$. The high loss of SOC in the forest zone is probably due to high erosion intensity.

Landslide is a common phenomenon and has affected about $15 \%$ of the catchment. Field observations showed that the landslide was initiated by crack formation in areas having smectite, a mineral which can swell and contract, depending on the availability of water. Most of the landslides occurring in the forest areas were observed where the canopy cover is less than $15 \%$ with slope of $10-40 \%$.

\subsection{Ideas and Suggestions of Local Inhabitants}

\subsubsection{Knowledge Sources of Local Inhabitants about Soil Science}

The education levels of the respondents were guidance school (25.60\%), high school (23.17\%), primary school (15.85\%) and higher education (14.63\%) and about $21 \%$ of them were illiterate. 
Mosayeb Heshmati et al. / American Journal of Applied Sciences 10 (9): 1061-1076, 2013

Table 3. Spatial distribution of topography, erosion and land use properties within the agro-ecological zones in the Merek catchment

\begin{tabular}{|c|c|c|c|c|c|c|c|}
\hline \multirow{3}{*}{$\begin{array}{l}\text { Facies } \\
\text { code }\end{array}$} & \multicolumn{3}{|c|}{ Topographic } & \multirow{3}{*}{$\begin{array}{l}\text { Erosion } \\
\text { Feature }\end{array}$} & \multirow[b]{3}{*}{ land use } & \multirow{2}{*}{\multicolumn{2}{|c|}{ Area }} \\
\hline & \multirow{2}{*}{$\begin{array}{l}\text { Slope } \\
(\%)\end{array}$} & \multirow[b]{2}{*}{ Aspect } & \multirow{2}{*}{$\begin{array}{l}\text { Altitude } \\
\text { (m) }\end{array}$} & & & & \\
\hline & & & & & & ha & $(\%)$ \\
\hline$\overline{\mathrm{A} 1}$ & $5-10$ & $\mathrm{P}$ & $1420-1600$ & Rill erosion & Rain-fed cereal & 175.54 & 0.76 \\
\hline $\mathrm{A} 2$ & $10-20$ & $\mathrm{~S}$ & $1600-1800$ & Rill erosion & Rain-fed cereal & 1054.22 & 4.58 \\
\hline A3 & $5-10$ & $\mathrm{P}$ & $1600-1800$ & Rill erosion & Rain-fed cereal & 531.70 & 2.34 \\
\hline A4 & $5-10$ & $\mathrm{P}$ & $1420-1600$ & Gully & Cereal & 884.75 & 3.84 \\
\hline A5 & $0-5$ & $\mathrm{P}$ & $1420-1600$ & Rill erosion & Cereal & 1497.14 & 6.50 \\
\hline A6 & $0-5$ & $\mathrm{P}$ & $1420-1600$ & Gully & Mainly irrigated crop & 2196.36 & 10.40 \\
\hline A7 & $0-5$ & $\mathrm{P}$ & $1420-1600$ & Inter-rill - Gully & Irrigate cereal & 1587.18 & 6.90 \\
\hline A8 & $5-10$ & $\mathrm{~N}$ & $1420-1600$ & Gully & Rain-fed cereal & 491.22 & 2.13 \\
\hline A9 & $5-10$ & $\mathrm{~N}$ & $1420-1600$ & Gully & Rain-fed cereal & 925.13 & 4.02 \\
\hline A10 & $5-10$ & $\mathrm{~N}$ & $1420-1600$ & Gully & Rain-fed cereal & 491.32 & 2.13 \\
\hline A11 & $10-20$ & $\mathrm{~N}$ & $1600-1800$ & Gully & Rain-fed cereal & 406.77 & 1.76 \\
\hline $\mathrm{A} 12$ & $5-10$ & $\mathrm{~N}$ & $1600-1800$ & Gully & Rain-fed cereal & 662.13 & 2.87 \\
\hline A13 & $10-20$ & $\mathrm{~S}$ & $1600-1800$ & Inter-rill - Gully & Mainly irrigated crop & 267.64 & 1.16 \\
\hline A14 & $0-5$ & $\mathrm{P}$ & $1420-1600$ & Inter-rill - Rill & Rain-fed cereal & 437.88 & 1.90 \\
\hline A15 & $10-20$ & $\mathrm{~S}$ & $1420-1600$ & Gully & Rain-fed cereal & 556.54 & 2.41 \\
\hline A16 & $0-5$ & $\mathrm{P}$ & $1600-1800$ & Inter-rill - gully & Rain-fed cereal & 496.72 & 2.16 \\
\hline A17 & $5-10$ & $\mathrm{~N}$ & $1600-1800$ & Gully & Rain-fed cereal & 547.16 & 2.37 \\
\hline A18 & $0-5$ & $P$ & $1600-1800$ & Gully & Irrigated + rain-fed & 601.56 & 2.61 \\
\hline A19 & $10-20$ & $\mathrm{~N}$ & $1600-1800$ & Inter-rill - gully & Irrigated crops & 208.75 & 0.90 \\
\hline $\mathrm{A} 20$ & $10-20$ & $\mathrm{~S}$ & $1600-1800$ & Inter-rill - rill & Rain-fed cereal & 251.25 & 1.09 \\
\hline $\mathrm{A} 21$ & $10-20$ & $\mathrm{~S}$ & $1600-1800$ & Inter-rill - rill & Rain-fed cereal & 242.80 & 1.05 \\
\hline $\mathrm{A} 22$ & $5-10$ & $\mathrm{~S}$ & $1800-2000$ & Inter-rill - rill & Rain-fed cereal & 296.24 & 1.28 \\
\hline $\mathrm{R} 1$ & $20-40$ & $\mathrm{~S}$ & $1800-2000$ & Snowing & grazing & 156.14 & 0.68 \\
\hline $\mathrm{R} 2$ & $>40$ & $\mathrm{~S}$ & $1800-2000$ & Snowing & grazing & 136.60 & 0.60 \\
\hline R3 & $10-20$ & $\mathrm{~S}$ & $1600-1800$ & Rill - Inter-rill & grazing & 341.53 & 1.48 \\
\hline $\mathrm{R} 4$ & $>40$ & $\mathrm{~S}$ & $1800-2000$ & Snowing & grazing & 361.08 & 1.57 \\
\hline R5 & $10-20$ & $\mathrm{~S}$ & $1500-1600$ & Rill - sheet & Grazing & 340.55 & 1.47 \\
\hline R6 & $20-40$ & $\mathrm{~S}$ & $1800-2000$ & Snow & Grazing & 118.10 & 0.52 \\
\hline R7 & $>40$ & $\mathrm{~S}$ & $2400-2600$ & Snow & Wild live & 634.33 & 2.75 \\
\hline $\mathrm{R} 8$ & $20-40$ & $\mathrm{~S}$ & $1800-2000$ & Sheet - Inter-rill & grazing & 361.08 & 1.57 \\
\hline R9 & $20-40$ & $\mathrm{~S}$ & $2000-2200$ & Sheet - rill & grazing & 448.91 & 1.95 \\
\hline $\mathrm{R} 10$ & $>40$ & $\mathrm{~S}$ & $>2400$ & Snow & Wild live & 224.46 & 0.97 \\
\hline $\mathrm{R} 11$ & $>40$ & $\mathrm{~S}$ & $2000-2200$ & Sheet -Inter- rill & grazing & 253.73 & 1.11 \\
\hline $\mathrm{R} 12$ & $>40$ & W & $2200-2400$ & Snow & Wild live & 292.75 & 1.26 \\
\hline $\mathrm{R} 13$ & $10-20$ & $\mathrm{~S}$ & $1800-200$ & Sheet - Inter-rill & grazing & 283.00 & 1.23 \\
\hline $\mathrm{R} 14$ & $20-40$ & $\mathrm{~N}$ & $1800-2000$ & Sheet - Inter-rill & grazing & 234.20 & 1.02 \\
\hline R15 & $20-40$ & $\mathrm{~S}$ & $1800-2000$ & Sheet - Inter-rill & grazing & 239.09 & 1.03 \\
\hline R16 & $10-20$ & W & $1600-1800$ & Sheet - Inter-rill & grazing & 331.75 & 1.44 \\
\hline $\mathrm{R} 17$ & $>40$ & $\mathrm{~S}$ & $2000-2200$ & Sheet - Inter- rill & grazing & 249.83 & 1.10 \\
\hline $\mathrm{R} 18$ & $20-40$ & $\mathrm{~N}$ & $1800-2000$ & Gully & grazing & 439.15 & 1.91 \\
\hline $\mathrm{R} 19$ & $20-40$ & $\mathrm{~N}$ & $1600-1800$ & Piping-Landslide & grazing & 243.97 & 1.11 \\
\hline $\mathrm{R} 20$ & $10-20$ & $\mathrm{~N}$ & $1600-1800$ & Landslide & grazing & 536.74 & 1.03 \\
\hline $\mathrm{R} 21$ & $20-40$ & $\mathrm{~S}$ & $1800-2000$ & Piping-Landslide & grazing & 239.07 & 1.04 \\
\hline $\mathrm{R} 22$ & $10-20$ & $\mathrm{~S}$ & $1600-1800$ & Piping-Landslide & grazing & 166.00 & 0.72 \\
\hline $\mathrm{F} 1$ & $10-20$ & $\mathrm{~N}$ & $1500-1600$ & Piping-Landslide & Illegal grazing & 170.00 & 0.74 \\
\hline $\mathrm{F} 2$ & $10-20$ & $\mathrm{~N}$ & $1600-1800$ & Piping-Landslide & Illegal grazing & 556.02 & 2.41 \\
\hline F3 & $20-40$ & $\mathrm{~N}$ & $1700-1900$ & Piping-Landslide & Illegal grazing & 870.05 & 3.77 \\
\hline Total & & & & & & 23038.13 & 100.00 \\
\hline
\end{tabular}

$\mathrm{Ai}=$ Agriculture zone, $\mathrm{Ri}=$ Rangeland zone, $\mathrm{Fi}=$ Forest zone, $\mathrm{P}=$ Plain, $\mathrm{S}=$ South, $\mathrm{N}=$ North, $\mathrm{W}=\mathrm{West}, \mathrm{E}=\mathrm{East}, \mathrm{P}=\mathrm{Plain}$ 
It was found that their knowledge about soils and soil erosion was inherited from their elders as well as getting from public media (especially local TV and radio). Other sources were governmental training and workshop, which enhanced about $5.4 \%$ of their knowledge. Site visits were conducted to show the respondents simple methods for run-off harvesting using fragmental rocks and making hollow around trees. Most of the respondents were happy with the programs on gathering new ideas and experiences.

\subsection{Information about Soil and Land Degradation}

To the question "why is soil important to you", the inhabitants said that soil was more important medium for crop production than water storage (49 and 19.9\% respondents, respectively). The importance of soil for livestock was ranked third by the respondents. Other important ideas about soil were for flood control, treatment of wastes and burial of the dead. The result of this simple question showed that there was no information on soil's contribution to the environmental issues, such as carbon sequestration and sedimentation.

\subsection{Causes of Land Degradation in the Opinion of Local Inhabitants}

Table 4 shows the causes of land degradation in the Merek catchment in the opinion of local inhabitants. Cultivation without rotation and fallow was first the ranked causing land degradation $(18.1 \%$ of all the scores). Although most of them knew that it was an improper activity and they preferred continued cultivation in order to increase yearly income. Tillage was ranked second contributing to land degradation in the respondents' opinions. Although they knew that most of the tillage in the hilly areas was not suitable, they continued doing it. Field observations showed that it was done mainly by smallholders. Haileslassie et al. (2005) reported that erosion induced by heavy tillage in the smallholding caused $70 \%$ losses in N, P and $\mathrm{K}$ from the soils of Ethiopia.

Crop residue burning was the third cause of land degradation in the opinion of local inhabitants.

In their experience, crop residues on the land promoted frost and pest hazard for the shoots and young roots. This is due to tillage practice by moldboard plow, which turnover most parts of the residues into the soils. A study by Titi (2003) showed $85 \%$ of the crop residues were overturned into the soils by this tillage tool. Conversion of rangelands into rain-fed areas and forest clearance were fourth and fifth rank, respectively causing land degradation. The inhabitants ranked flood as the sixth factor.

Over usage of chemical fertilizers and pesticides was ranked as seventh factor, causing land degradation (8.3\% of all the scores). They knew that excess application of these materials would affect bread quality, although crop yield was improved. They did not know about the environmental and economic impacts of over application of these chemicals. It is well know for sure that pesticide poisoning leads to significant financial burden on individual families and the public health system (Sherwood et al., 2008). Fire in the rangeland and forest occurring mainly in September was ranked eighth in the opinion of the respondents. Overgrazing and waste deposal were ranked ninth and tenth, respectively. Domestic sewage and sludge deposal pollute the agricultural areas in the lower parts of Halashi, Najafabad and Sarab-e-Sarfiruzabad villages. Mining, road construction and nomads only cause about $2.6 \%$ of the land degradation. Plastic bag, rubbish, manures, chicken dung and dusts were stated as the other factors causing land degradation.

Table 4. Prioritized causes of land degradation in the opinion of the local inhabitants

\begin{tabular}{|c|c|c|c|c|c|c|c|}
\hline \multirow[b]{2}{*}{ Rank } & \multirow[b]{2}{*}{ Causes } & \multicolumn{2}{|l|}{ Scores* } & \multirow[b]{2}{*}{ Rank } & \multirow[b]{2}{*}{ Causes } & \multicolumn{2}{|l|}{ Scores } \\
\hline & & Num** & $\%$ & & & Num* & $\%$ \\
\hline 1 & Cultivation without rotation and fallow period & 48 & 18.1 & 9 & Over grazing & 8 & 3.1 \\
\hline 2 & Improper tillage practices (up to down the slope) & 34 & 13.8 & 10 & Waste disposal & 7 & 2.5 \\
\hline 3 & Crop residual burning & 32 & 12.9 & 11 & Others $* * *$ & 5 & 2.0 \\
\hline 4 & Conversion of rangelands to agricultural areas & 30 & 12.4 & 12 & mining & 3 & 1.0 \\
\hline 5 & Deforestation & 23 & 9.7 & 13 & Road construction & 2 & 0.8 \\
\hline 6 & Sever flood & 21 & 8.7 & 14 & Nomads & 2 & 0.8 \\
\hline 7 & Over utility of chemical fertilizer and pesticides & 20 & 8.3 & 15 & Industrials effects & 0 & 0.0 \\
\hline 8 & Fire (in the rangeland and forest) & 11 & 4.6 & & & & \\
\hline
\end{tabular}

*: Based on respondents suggestion, ${ }^{* *}$ : Num $=$ numbers of respondents, ***: Others including increase in rubbish (plastic bag and can) during recent years, dusts in spring season, because some farmer believed that it can fail yield cops 


\subsection{Inhabitant's Perception on Possible Solutions of Land Degradation}

The ranking on the possible solutions to land degradation is shown in Table 5. Fallow and rotation period were seen the best solution $(15.4 \%$ of all the score). They currently do not use this method due to financial reason. Effective extension was ranked second for the possible solution to the problem $(13.9 \%)$ as this work would enhance their skill and knowledge on cropping, animal husbandry, handling of machinery and poultry. Development of orchard and tree plantation was ranked as the third possible method. Recently, farmers have planted fruit trees such as almond, walnut and vineyard, especially along the borders of their irrigated fields. Seeding in the rangeland and controlling the crops residual burning were ranked fourth and fifth solutions, respectively.

Forage cultivation on steep slopes was ranked sixth solution by the respondents (mainly by nomads and herders); forage can supply part of their demand for fodder, especially alfalfa, clover and barley in the winter season. Optimum usage of chemical fertilizers and pesticides was ranked seventh possible solution in the agricultural areas. Field observations and experiences of local administrators showed that this option is important in the irrigated lands subjected to over usage of chemical fertilizers. Forest conservation by government agencies and fire control were ranked eighth and ninth solutions, respectively. They very well knew that forest was being cleared and damaged through wildfire due to insufficient monitoring by the responsible agency. They ranked strip cropping as the tenth possible measure for soil conservation in sloping lands.

Controlling improper tillage (up-down the slope) was ranked the same as strip cropping. Field observations showed that these agricultural lands were characterized by small size (less than one ha) and were rectangular in shape that laid parallel to the slope length and perpendicular to tillage practices. Technical methods such as earth dam, check dam and terracing were ranked as eleventh possible method. Most of the local inhabitants, especially nomads and herders disagreed with the control of overgrazing and preservation of the rangeland by government agencies.

\subsection{Human-Induced Land Degradation from Expert's Perception: In the Agricultural Areas}

Table 6 shows the ranking of human-induced land degradation factors in the agricultural areas by relevant experts. Improper tillage practice (up-down the slope) in the hilly lands was ranked first ( 32 scores). This is so because of excessive usage of agricultural machinery, estimated to be about 500 tractors (ASCH, 2008). Plowing using modern machinery is the most destructive recent development for cultivation of winter cereals on an annual basis. Increased conversion of the rangelands and forest to rain-fed areas and up-down the slope tillage has resulted in the severe erosion and sedimentation. As shown in Fig. 2 and Table 3, 4257 ha $(18.5 \%)$ of the study area $\left(\mathrm{A}_{1}, \mathrm{~A}_{2} \mathrm{~A}_{3}, \mathrm{~A}_{5}, \mathrm{~A}_{14}, \mathrm{~A}_{15}, \mathrm{~A}_{20} \mathrm{~A}_{21}\right.$ and $\left.\mathrm{A}_{22}\right)$ are characterized by steep slope $(10-20 \%)$ and mostly subjected to inter-rill and rill erosion.

Table 5. Prioritized possible solutions of land degradation in the opinion of local inhabitants

\begin{tabular}{|c|c|c|c|c|c|c|c|}
\hline \multirow[b]{2}{*}{ Rank } & \multirow[b]{2}{*}{ Solutions method } & \multicolumn{2}{|l|}{ Scores } & \multirow[b]{2}{*}{ Rank } & \multirow[b]{2}{*}{ Solutions method } & \multicolumn{2}{|l|}{ Scores } \\
\hline & & Num* & $\%$ & & & Num* & $\%$ \\
\hline 1 & Fallow and rotation periods & 56 & 15.6 & 8 & $\begin{array}{l}\text { Forest protection by } \\
\text { government intervention }\end{array}$ & 20 & 5.6 \\
\hline 2 & $\begin{array}{l}\text { Training and extension } \\
\text { Fire control in the forest and range (by penalty) }\end{array}$ & 50 & 13.9 & 9 & & 18 & 5.1 \\
\hline 3 & Orchard and tree planting & 48 & 13.4 & 10 & Strin cropning at the hill slope & 16 & 4.5 \\
\hline 4 & Seeding in the rangeland & 32 & 9.0 & 11 & $\begin{array}{l}\text { Controling the improper } \\
\text { tillage by penalty or levy }\end{array}$ & 16 & 4.5 \\
\hline 5 & $\begin{array}{l}\text { Control of crops residual burning } \\
\text { (by penalty or levy) }\end{array}$ & 27 & 7.5 & 12 & $\begin{array}{l}\text { Technical methods (Earth dam, } \\
\text { check dam,terracing,...) }\end{array}$ & 12 & 3.4 \\
\hline 6 & Forage cultivation on the steep slops & 24 & 6.7 & 13 & $\begin{array}{l}\text { Overgrazing control with } \\
\text { participation of stakeholders }\end{array}$ & 10 & 2.8 \\
\hline 7 & $\begin{array}{l}\text { Optimum usage of chemical fertilizers } \\
\text { and pesticides }\end{array}$ & 21 & 5.8 & 14 & $\begin{array}{l}\text { Preservation of rangeland } \\
\text { with government intervention }\end{array}$ & 8 & 2.2 \\
\hline
\end{tabular}

* Num $=$ numbers of respondents 
Table 6. The ranking of human- induced land degradation in the agricultural area in the opinions of relevant expert

\begin{tabular}{|c|c|c|c|}
\hline \multirow[b]{2}{*}{ Rank } & \multirow[b]{2}{*}{ Factors } & \multicolumn{2}{|c|}{ Scores* } \\
\hline & & Numb & $\%$ \\
\hline 1 & Improper tillage practices (up to down the slope) & 32 & 14.0 \\
\hline 2 & Crop residual burning & 29 & 11.1 \\
\hline 3 & Cultivation without rotation and fallow periods & 27 & 10.0 \\
\hline 4 & Over application of chemical fertilizers, pesticide and herbicide & 25 & 9.4 \\
\hline 5 & Conversion of rangeland to rain-fed croplands & 22 & 8.3 \\
\hline 6 & Conversion of the wetland, grassland and border of stream, river and drainage to agricultural areas & 20 & 7.7 \\
\hline 7 & Economical issues (mainly poverty and insufficient incomes) & 18 & 6.6 \\
\hline 8 & Shortcoming of current laws and official monitoring & 17 & 6.5 \\
\hline 9 & Lobbies (local pressure groups) & 16 & 6.1 \\
\hline 10 & Improper land leveling and changing of natural drainage systems & 15 & 5.5 \\
\hline 11 & Conflicts & 15 & 5.1 \\
\hline 12 & Unsuitable road constriction & 12 & 4.4 \\
\hline 13 & Fires making & 8 & 3.0 \\
\hline \multirow[t]{2}{*}{14} & Unsuitable surface mines activities & 6 & 2.3 \\
\hline & Total & 262 & 100.0 \\
\hline
\end{tabular}

*: Based on suggestions of the relevant experts

Gully erosion at $A_{9}, A_{10}, A_{13}, A_{17}$ and $A_{18}$ (with 2831 ha) is promoted by soil mineralogy (smectite) and is made worse by improper tillage practices, especially in the south part of the study area. About 7089 ha of the Merek catchment (about $48 \%$ of agricultural areas) is suffering from improper tillage practices, resulting in accelerated soil erosion and consequently, soil productivity is lowered. It is known the soil fertility in the smallholdings of the marginal rainfall areas rapidly decline due to erosion or continuous cropping. This improper tillage practice affects soil aggregate stability, which in turn, increases soil erosion.

Crop residues burning and cultivation without fallow and rotation periods were ranked second and third, respectively. In the hilly areas, exposed soils through plowing are easily detached by rainfall in autumn season unless cultivated seeds grow up quickly and produce good canopy cover within a short time. The application of chemical fertilizers and crop residues burning were two important challenges in the opinions of the experts. As shown in Table 7, the average grain yield of rain-fed wheat is $1000 \mathrm{~kg} \mathrm{ha}^{-1}$, while the irrigated wheat yield is $4325 \mathrm{~kg} \mathrm{ha}^{-1}$. Barley grain is used for animal fattening, while most of the wheat is purchased by the government at guaranteed price. Crop residues production in the rain-fed and irrigated wheat and barley areas are 1.7 and $5.5 \mathrm{t} \mathrm{ha}^{-1}$, respectively; chemical fertilizer usage in the irrigated lands is at least two times more than rain-fed farms.

The demand for chemical fertilizers has been increasing over the years due to the policy of selfsufficiency for wheat consumption, resulting in the farmers to continuously cultivate the land. As a result, the poor farmers, who are not able to buy additional fertilizers from the free market, apply less fertilizer, while the better-off farmers usually buy and apply more fertilizers than the crops required (Milani et al., 2006). Farmers often use their own judgment during fertilizer application. In the upper catchment of Karkheh basin (including Merek catchment) recommendation for plant nutrition are often not adopted by farmers due to insufficient extension services.

Field observations showed that wheat and barley stubbles were mostly left on the field after harvesting. Stubbles are mainly used for animal feed during the winter. The remaining residues were burnt in late August to early September, before the next cropping. Crop residues burning contribute to the global warming through $\mathrm{CO}_{2}$ emission. Yang et al. (2008) reported that about $82 \%$ of wheat straw and $37 \%$ of rice straw were burnt in the field in China, which emitted about 2.2 million $\mathrm{t}$ of $\mathrm{CO}_{2}$ to the atmosphere. Iran also shares about $1.5 \%$ of the global $\mathrm{CO}_{2}$ emission, which increased from 218.3 (1990) to $433.3 \mathrm{Mt} \mathrm{CO}_{2}$ (2004), mainly due to agricultural activities such as crop residues burning United Nation Development Program, 2009.

Converting of rangelands into agricultural areas was ranked fifth as the cause of land degradation and conversion of the wetland and borders of river to agricultural areas was ranked sixth. Shortcoming of relevant laws and ineffective official monitoring was ranked eighth as the cause of land degradation. In the respondents' opinion, the contribution of local lobbies (pressure groups) was ranked ninth. They blamed rich people for illegally causing land alienation from forest to mining land. Improper land leveling was ranked tenth. 
Mosayeb Heshmati et al. / American Journal of Applied Sciences 10 (9): 1061-1076, 2013

Table 7. The average grain yield, crop residues and chemical fertilizer usage in Kermanshah province (including Merek catchment)

\begin{tabular}{|c|c|c|c|c|c|c|}
\hline \multirow[b]{2}{*}{ Rain-fed } & \multirow[b]{2}{*}{ crop } & \multirow{2}{*}{$\begin{array}{l}\text { Average yield } \\
\mathrm{kg} \mathrm{ha}^{-1}\end{array}$} & \multirow{2}{*}{$\begin{array}{l}\text { Average crop residues } \\
\text { ton } \mathrm{ha}^{-1}\end{array}$} & \multicolumn{3}{|c|}{ chemical fertilizer $\mathrm{kg} \mathrm{ha}^{-1}$} \\
\hline & & & & $\mathrm{K}_{2} \mathrm{O}$ & $\mathrm{P}_{2} \mathrm{O}_{5}$ & $\mathrm{~N}$ \\
\hline \multirow{10}{*}{ Irrigated } & Wheat & 1000 & 1.8 & 60 & 32 & 25 \\
\hline & Barley & 980 & 1.5 & 50 & 20 & 20 \\
\hline & Chickpea & 580 & - & 23 & 14 & - \\
\hline & Wheat & 4325 & 6 & 115 & 46 & 50 \\
\hline & Barley & 3568 & 5 & 100 & 40 & 40 \\
\hline & Maize & 7,800 & 20 & 230 & 92 & 50 \\
\hline & Sugar beet & 35,300 & 11 & 185 & 70 & 50 \\
\hline & Potato & 18,580 & 12 & $300-350$ & $100-200$ & $100-150$ \\
\hline & Alfalfa & 8,270 & 8 & 46 & $23-46$ & - \\
\hline & Cash crop & 17,000 & $20-25$ & 275 & 135 & \\
\hline
\end{tabular}

All the farmers using $\mathrm{N}$ and $\mathrm{P}_{2} \mathrm{O}_{5}$ fertilizers, but half of the farmers using also the rest nutrients. (Source: Milani et al., 2006)

Conflict was scored as the eleventh contribution to land degradation in the agricultural areas. In most areas of the semi-arid region, land use change contributes to soil erosion, run-off and muddy floods (Boardman et al., 2003). Unsuitable road construction was ranked as the last cause of land degradation in the agricultural areas.

\subsection{In the Rangeland Areas}

As shown in Table 8, overgrazing was ranked first for causing land degradation in the rangeland by the experts. They stated that the current stocking rates were five to ten times more than the rangeland capacity. This happens because of the shortcoming of responsible officers, socio-economical problems, decrease in rangeland areas and free grazing. The impacts of severe grazing were trampling, soil displacement, reduction of grasses and increasing runoff and erosion (Blanco-Canqui et al., 2008). Field verifications showed that some desirable plants such as Festuca ovina and Prangus sp were diminishing, while unpalatable species such as Daphenea $s p$ and Astragalus sp were increasing. Heavy sheep and goat grazing have resulted in severe depletion and browsing of desirable plants in the field (Salem, 2004). Respondents addressed the importance of increased grazing by animals belonging to nomads in summer.

Conversion of rangeland to rain-fed areas and poverty were ranked second and third causing land degradation, respectively. It is found that local people focus on their immediate needs rather than on the longterm benefits because of poverty, especially in the rainfed areas of the marginal lands. Merek catchment is characterized by small size, high soil erosion and improper land use activities.
Marginal dry lands are vulnerable to land degradation. These areas are usually suffering from recurrent drought, water shortage, shallow soils and land degradation (Thomas, 2004). This occurs because of the shortage of income-generating resources, which make local inhabitants more dependent on the natural resources present in the areas (Alqawabah et al., 2004).

An investigation by Najafi and Shooshtarian (2007) showed that poverty line in the rural areas of Iran was widespread due to large household size and the higher number of unemployed persons as compared to the urban areas. Additionally, the share of agriculture sector in job-creation in Iran has been decreasing over the years $(65 \%$ in 1956 to $22.7 \%$ in 2006$)$ as compared to manufacturing and service sectors (Baseri and Jahangard, 2007). The study of Rafati et al. (2009) showed that about $45.6 \%$ of resident households in the Merek catchment were poor (under poverty line) and the average annual income of each household was 2,824,5930 Iranian currency (about 2800 USD).

Conflict was ranked fourth for causing land degradation in the rangelands (disputes among nomads, farmers, herders and people who harvest by-products such as tragacanth and gum). These conflicts contribute to the land degradation through increasing competition for animal grazing, tree logging and change of land use. They pointed it out that the conflict between the local people and administrative office is serious. The officer has persuaded the local people to stop their illegal activities such as charcoal extraction and tillage practice in the forest and rangeland. Nesbitt and Weiner (2001) reported that there was a conflict of interest between land owners and environmentalist on the extraction of natural resources. The respondents stated that the current laws and administrative office were unable to confine the current level of land degradation in the study area. 
Table 8. The ranking of human- induced land degradation in the rangeland area in the opinions of relevant expert

\begin{tabular}{|c|c|c|c|}
\hline \multirow[b]{2}{*}{ Rank } & \multirow[b]{2}{*}{ Factors } & \multicolumn{2}{|l|}{ Scores } \\
\hline & & Number & $\%$ \\
\hline 1 & Over grazing & 37 & 16.1 \\
\hline 2 & Conversion of rangeland to rain-fed areas & 34 & 14.0 \\
\hline 3 & Poverty and insufficient yearly income & 27 & 11.8 \\
\hline 4 & Conflicts & 24 & 10.4 \\
\hline 5 & Shortcoming of current laws and administrative office & 23 & 9.8 \\
\hline 6 & Lobby (local pressure groups) & 19 & 8.2 \\
\hline 7 & Fire & 16 & 7.0 \\
\hline 8 & Cultivation in the wetland, grassland and stream border & 15 & 6.4 \\
\hline 9 & Unsuitable road constriction & 14 & 6.0 \\
\hline 10 & Improper mining & 13 & 5.6 \\
\hline \multirow[t]{2}{*}{11} & Illegal land leveling and changing of natural drainage system, using heavy machinery (bulldozers, ...) & 11 & 4.7 \\
\hline & Total & 233 & 100.0 \\
\hline
\end{tabular}

Local lobbies and fire were ranked as sixth and seventh factors contributing to land degradation in the rangeland. In the opinion of the experts, fire was caused by arsonists who remove native plants. Land use alteration of the wetlands, which are located in natural spring and stream borders, was ranked as the eighth factor for land degradation. These areas are nationalized by the government and play an important role in the environmental services and soil conservation. The relevant experts ranked unsuitable road construction as the ninth cause of land degradation. Most of the roadsides are not protected by facilities such as gabion, seeding and rock pavements. Improper mining activities occur near the border of Merek catchment. Some farmers apply land leveling and illegally convert rangeland to agricultural areas using heavy machinery.

The experts specified the following as the other causes of land degradation:

- Illegal transaction of grazing license between herders and nomads

- Nomads and herders having more than one job

- Increased usage of traditional medicine (extraction of herbal plant species)

- Military activities in the area

- Destruction of natural vegetation

\subsection{In the Forest Areas}

Table 9 shows the categorized causes of deforestation by relevant experts. Forest clearing was the first factor causing deforestation (with 37 scores). They indicated that this illegal activity has been increasing in recent years. Forest tree density in the Merek catchment is less than $15 \%$ (Ghitori and Tavakoli, 2008). Tree logging and plowing are mainly carried out near the boundary between agricultural areas, resulting in the reduction of biodiversity. However, logging provides a flush of nutrient-rich litter in the form of logging debris (Newton, 2007).

Both nomads and villagers attempt to have illegal livestock in the forest. This factor was the second cause of deforestation. It happens because of insufficient administrative staff supervising the areas and socioeconomical problems such as poverty and intervention of some powerful persons (as the lobbies). Fire, especially arson fire, was ranked third as the cause of deforestation because of charcoal extraction. The respondents clarified that charcoal extraction and forest clearance were mainly done by poor and jobless people who were living near the forest. Root cutting of the forest tree in the border between agricultural areas was the fourth factors of deforestation. The shortcoming of current laws and administrative office was ranked sixth as the cause of land degradation. Conflict was ranked seventh. In opinions of the experts, surface mining has been increasing recent years.

Some nomads dwell in the forest during grazing periods and cut the trees for making temporary home, resulting in the forest destruction. The respondents emphasized that lobbies (local pressure groups) forced administrative staff to carry out illegal activities such as charcoal extraction, improper mining activities and grazing. They ranked lobbies factor as the tenth cause of deforestation. Unsuitable road constriction and tree branch cutting were eleventh and twelfth ranks causing land degradation, respectively.

Land degradation by non-agricultural activities such as road construction, mining and military activities can lead to fires, soil compaction and forest clearance. Silveira et al. (2009) showed the degradation of soil structures and severe soil erosion were caused by intensive military activities. 
Table 9. The ranking of human-induced land degradation in the forest area in the opinions of relevant expert

\begin{tabular}{|c|c|c|c|}
\hline \multirow[b]{2}{*}{ Rank } & \multirow[b]{2}{*}{ Factors } & \multicolumn{2}{|c|}{ Scores } \\
\hline & & Score & $\%$ \\
\hline 1 & Conversion of the forest into the cultivated land & 37 & 12.6 \\
\hline 2 & Livestock grazing & 32 & 10.8 \\
\hline 3 & Fire (special forest and range on border of farm) & 28 & 9.5 \\
\hline 4 & Root cutting of the forest trees in border of the agricultural areas & 27 & 9.2 \\
\hline 5 & Poverty, low income & 25 & 8.5 \\
\hline 6 & Shortcoming of current laws and administrative office & 23 & 8.1 \\
\hline 7 & Conflicts & 22 & 7.8 \\
\hline 8 & Improper mining & 21 & 6.8 \\
\hline 9 & Temporary residence of nomad in the forest & 20 & 6.8 \\
\hline 10 & Lobby (local pressure groups) & 18 & 6.5 \\
\hline 11 & Unsuitable road constriction & 14 & 4.8 \\
\hline 12 & Tree branch cutting & 13 & 4.5 \\
\hline 13 & Illegal land leveling and changing of natural drainage system, using heavy machinery (bulldozers, ...) & 4.1 & 12.0 \\
\hline Total & & 292 & 100.0 \\
\hline
\end{tabular}

\subsection{Ranking of Solution Options by the Relevant Experts}

\subsubsection{In the Agricultural Areas}

The prioritized possible solutions for controlling the improper agricultural activities scored by relevant experts are shown in Table 10. Most of the relevant experts emphasized on effective training and extensions as the first possible solution. This is because farmers are a central part of the process of innovation and adaptation of resource conserving technologies (Pretty and Shah, 2008). Farmers in the dry lands are lack of appropriate information and technological knowledge, unclear of land right and policy, have inadequate financial sources for adopting new technology and unable to purchase inputs (Thomas, 2004). The respondents indicated that knowledge and skills of farmers should be improved through extension activities for sustainable agricultural production. In their opinion, the responsibility of the inhabitants to environmental issues such as $\mathrm{CO}_{2}$ emission is low. Improving tillage practice through reduced tillage, no-till or sub-soiling tillage not only contribute to improvement in land productivity, but also help reduce soil erosion (Gabriels et al., 2003).

Participation of stakeholders in soil conservation measures (such as run-off harvesting and strip cropping) was ranked second possible solution for agricultural areas; this is because the government cannot carry out any program without coordinating the local people. Enactment of new laws and amending of the current laws was third option, especially for input application (fertilizers and pesticides), tillage practices and crop residues burning. Introduction of new technologies for agricultural activities such as tillage practice, crop cultivation, irrigation and deeper turnover of crop residues can mitigate land degradation in the agricultural areas. These appropriate technologies should be introduced to the agricultural smallholders (Nosyrov, 2004).

Encouraging the farmers to increase forage production such as alfalfa and clover was ranked fifth possible solution by the respondents. They stated that this work not only would mitigate land degradation through reduction of grazing pressure on the rangelands, but also contributed nitrogen via fixation by the root system.

The following options were specified by relevant experts, which indirectly result in mitigation of land degradation in the agricultural areas:

- Adequate insurance for rural people

- Improving the subsidy polic

- Supervision the heavy non-agricultural machinery, such as bulldozers in the rural areas

- Agro-forestry in the stony hilly slope with surface run-off harvesting

- Increasing investment in agriculture sector for job creation

- Reforming land tenure and ownership

- Encouraging the farmers for land consolidation and proper tillage practices

\subsection{In the Rangeland Areas}

The prioritized possible solutions for land degradation in the rangeland by relevant experts are shown in Table 11. Education and extension was the first important scenario for rangeland and agricultural areas. 
Mosayeb Heshmati et al. / American Journal of Applied Sciences 10 (9): 1061-1076, 2013

Table 10. The ranking of the possible solutions for land degradation in the agricultural areas in opinions of the relevant esperts

\begin{tabular}{|c|c|c|c|}
\hline \multirow[b]{2}{*}{ Rank } & \multirow[b]{2}{*}{ Solutions methods } & \multicolumn{2}{|l|}{ Scores } \\
\hline & & Number & $\%$ \\
\hline 1 & Training and extension & 56 & 28.1 \\
\hline 2 & Soil conservation measures with farmers' participation & 35 & 17.8 \\
\hline 3 & Enactment of new laws and amending of current laws & 32 & 16.1 \\
\hline 4 & Introducing new technology for sustainable agricultural activities & 30 & 15.0 \\
\hline 5 & Encouragement of farmers for forage cultivation such as alfalfa and clover. & 25 & 13.1 \\
\hline \multirow[t]{2}{*}{6} & Monitoring and effective supervision of non agricultural activities such as mining and road construction & 21 & 9.9 \\
\hline & Total & 199 & 100.0 \\
\hline
\end{tabular}

Table 11. The ranking of the possible solutions for land degradation in the rangelands areas in the opinions of the experts

\begin{tabular}{|c|c|c|c|}
\hline \multirow[b]{2}{*}{ Rank } & \multirow[b]{2}{*}{ Solutions methods } & \multicolumn{2}{|l|}{ Scores } \\
\hline & & Number & $\%$ \\
\hline 1 & Training and extension & 49 & 16.3 \\
\hline 2 & Preservation of critical areas & 37 & 12.5 \\
\hline 3 & Legislation and enact of new laws & 28 & 9.4 \\
\hline 4 & Soil conservation measures and rangeland management with local people participation & 27 & 9.2 \\
\hline 5 & Improving the current grazing systems & 25 & 8.5 \\
\hline 6 & Enactment of new laws and amending of current laws & 24 & 8.1 \\
\hline 7 & Empowering the natural resources offices & 23 & 7.8 \\
\hline 8 & Seeding in the degraded rangeland & 21 & 7.1 \\
\hline 9 & Levying of tax on grazing & 20 & 6.8 \\
\hline 10 & Utilization of new technology for rangeland management & 17 & 5.7 \\
\hline 11 & Monitoring and effective supervision on the non agricultural activities such as mining and road construction & 13 & 5.0 \\
\hline \multirow[t]{2}{*}{12} & Measuring of soil conservation and rangeland management projects without local people participation & 11 & 3.6 \\
\hline & Total & 295 & 100.0 \\
\hline
\end{tabular}

They found that most of the nomads and herders were not familiar with new techniques for animal husbandry (such as feeding, fattening and proper animal grazing). They believed that information on economical and environmental impacts of overgrazing should be enhanced. Periodic preservation (2-5 years) for regeneration of desirable plant species to improve soil physical properties in the severely grazed and destroyed sites was ranked second. They suggested that this should be done with the cooperation of herders and nomads.

Legislation and enactment of new laws was ranked the third as the possible solution. Current laws cannot control land degradation. Participation of the farmers in soil conservation measure was ranked fourth possible option. In their opinion, considerable part of soil conservation measures was deemed ineffective due to poor stakeholders' participation. Improving the current grazing systems through delayed grazing was ranked fifth. The respondents ranked the enactment of new laws and amending of current laws as the sixth possible options for particular issues such as grazing license, tax, penalty, ownership and arson fires. The respondents stated that the Forests, Rangelands and Watershed
Management Organization of Iran (FRWMOI) should be given more power and authority for effective protection of natural resources. Seeding was ranked eighth possible method for rehabilitation of the degraded rangeland, especially for desirable plant species which was diminishing or disappearing due to severe grazing.

Levying tax on grazing was the eighth factor. Currently, free grazing increases the stocking rate in the rangeland. Utilization of new technologies (such as GIS, GPS, especial seeding machine) and proper fire extinguisher was categorized as tenth possible method. Monitoring and supervision of non-agricultural activities (mainly mining and road construction) was ranked as eleventh possible solution in the rangelands. Only a few respondents agreed with the measures taken for soil conservation projects without cooperation of local people. They stated that rangelands and forests have been nationalized and rehabilitation programs should be done even without the participation of stakeholders. Encouraging the nomads and herders to improve their animal husbandry, insurance policy, allocating part of the rangelands for natural biodiversity reserves were specified by the respondents. 
Table 12. The ranking of the possible solutions for land degradation in the forest areas in the opinions of relevant experts

\begin{tabular}{|c|c|c|c|}
\hline \multirow[b]{2}{*}{ Rank } & \multirow[b]{2}{*}{ Solutions methods } & \multicolumn{2}{|l|}{ Scores } \\
\hline & & Number & $\%$ \\
\hline 1 & Preservation & 46 & 17.4 \\
\hline 2 & Education and extension & 40 & 15.2 \\
\hline 3 & Legislation and enact of new laws & 34 & 12.9 \\
\hline 4 & Enactment of new laws and amending of current law & 29 & 11.0 \\
\hline 5 & Empowering the natural resources offices & 27 & 10.2 \\
\hline 6 & Soil conservation measures and forestry with local people participation & 24 & 9.1 \\
\hline 7 & Monitoring and effective supervision on the non agricultural activities such as mining and road construction & 21 & 8.0 \\
\hline 8 & Soil conservation measures and forestry without local people participation & 17 & 6.4 \\
\hline 9 & Seedling and planting & 13 & 4.9 \\
\hline \multirow[t]{2}{*}{10} & Introducing new technology for sustainable forest management & 13 & 4.9 \\
\hline & Total & 264 & 100.0 \\
\hline
\end{tabular}

\subsection{In the Forest Areas}

The ranking by relevant experts for the possible methods of protecting the forest is as shown in Table $\mathbf{1 2}$. Preservation was the first and most important possible method for combating deforestation. They stated that these nationalized forests should be protected within natural parks and reserve sites for environmental services such as soil conservation, biodiversity and wildlife habitats as well as preventing soil erosion and improving drainage of the lowlands. In their opinion, effective protection can improve regeneration of forest species and increase density of key species such as Quecus persica and Pistacia sp. Forest conservation and restoration of native forest have become a major goal of governmental and non-governmental organization protection programs (Newton, 2007).

The experts ranked education and extension option as the second possible method for protection of the forest through increasing public awareness. The enactment of new laws and amending of the current laws was ranked as the forth possible factor. Increasing the penalty rate and effective trial of illegal activities (such as grazing, charcoal extraction, logging, fire making and plowing in the forest) are the ways to combat land degradation. Empowering the administrative offices was the fifth option for combating deforestation.

Soil conservation with stakeholder participation was ranked sixth. In their opinion, these projects would succeed if local people were recruited as laborers in the areas. Seeding and planting was ranked ninth solution for the forests areas. Seeding should be done under holistic approach and should include diminished species which cannot regenerate and avoid from forage species. Introducing new technology for fire extinguishing and field monitoring was ranked tenth.

The following issues were specified by the experts:
- Effective mapping and documentation of forests in each village

- $\quad$ Registering the unique forest trees

- Allocating considerable part of good forests for natural reserves

- Road construction for easy access to forest in the forest

- Combating poverty through job-creation, welfare and education

- Updating the skill and knowledge of executive officers through workshops

\section{CONCLUSION}

Merek catchment, Iran is subjected the accelerated land degradation caused by human-induced factors. The information and knowledge of the inhabitants on soils and soil erosion within the catchment are limited and are mainly inherited from their elders. They know that soils are an important media for crop production and water storage. In the opinion of the local inhabitants, improper tillage practices, crop residues burning, over utilization of chemical fertilizers and overgrazing are important causes of land degradation. However, the inhabitants still carry out these activities because of low income, poverty and the need for continued cultivation of crops for their survival. The relevant experts have the same views as those of the inhabitants about factors causing land degradation in the areas allocated to agriculture, rangeland and forest. Land and soil conservation measures with the participation of local people are the possible solutions to reduce land degradation. Effective extension, preservation, improving the current grazing systems, legislation of new laws and empowering government officers can somewhat reduce land degradation. The government as the main stakeholder in 
the area should provide more job opportunities and essential services to the poor farmers. These approaches are regarded as the way forward to curtail land degradation in the Merek catchment, Iran.

\section{ACKNOWLEDGMENT}

The researchers would like to acknowledge University Putra Malaysia (UPM) and Agricultural Research and Education Organization of Iran (AREO) for financial and technical support.

\section{REFERENCES}

Alqawabah, M.S., C. Johnson and M.Y. Alfattah, 2004. Assessment and evaluation methodologies report: Biosphere Reserve, Jordan. Proceeding of the 2nd International Workshop of Combating Desertification; Sustainable Management of Marginal Dry-Lands, (MMDL' 04), UNESCOMAB dry-lands, Shiraz, Iran, pp: 56-69.

ASCH, 2008. Total Tractors and Fertilizer Consumption in the Merek Catchment, Halashi, Kermanshah, Iran.

Ashrafi, N., 2003. Overview of Karkheh River Basin.

Baseri, B. and E. Jahangard, 2007. An examination of job-creation capacity in Iranian agriculture. EqtesadE Keshavarzi Va Towse'e, 15: 119-146.

Bechmann, M., P. Stalnacke, S. Kvaerno, H.O. Eggestad and L. Oygarden, 2009. Integrated tool for risk assessment in agricultural management of soil erosion and losses of phosphorus and nitrogen. Sci. Total Environ., 407: 749-759. PMID: 18940272

Blanco-Canqui, H., H. Blanco and R. Lal, 2008. Principles of Soil Conservation and Management. 1st Edn., Springer, ISBN-10: 1402087098, pp: 644.

Boardman, J., J. Poesen and R. Evans, 2003. Socioeconomic factors in soil erosion and conservation. Environ. Sci. Policy, 6: 1-6. DOI: 10.1016/S14629011(02)00120-X

Brunis, R.J.F. and M.T. Heberling, 2004. Economics and Ecological Risk Assessment: Applications to Watershed Management. 1st Edn., CRC Press, Boca Raton, ISBN-10: 0203486609, pp: 472.

Debarry, P.A., 2004. Watersheds: Processes, Assessment and Management. 1st Edn., Wiley, Hoboken, ISBN10: 0471264237, pp: 700.

Farshad, A. and N. Barrera-Bassols, 2003. Historical anthropogenic land degradation related to agricultural systems: Case studies from Iran and Mexico. Phys. Geography, 85: 277-286. DOI: 10.1111/j.0435-3676.2003.00205.x
Gabriels, D., W. Schiettecatte, K. Verbist and W. Cornelis, 2003. Water Harvesting in Southeast Tunisia and Soil Water Storage in the Semi-Arid Zone of the Loess Plateau of China. In: Sustainable Management of Marginal Drylands, Thomas, S (Ed.), Curran Publishing Services, Iran, pp: 19-24.

Ghitori, M. and A. Tavakuli, 2008. Vegetation Cover Inventory in Merek Site. Challenge Program on Water and Food and Agriculture and Natural Resources Research Center, Kermanshah, Iran.

Glavovic, B., R. Scheyvens and J. Overton, 2002. Waves of adversity, layers of resilience: Exploring the sustainable livelihoods approach. Institute of Development studies, Massey University, Palmerston North, N.Z.

Haileslassie, A. J.A. Priess, E. Veldkamp, D. Teketay and J.P. Lesschen, 2005. Assessment of soil nutrient depletion and its spatial variability on smallholding; mixed-farming systems in Ethiopia. Agric. Ecosyst. Environ., 108: 1-16.

Hashim, G.M. and W.Y.W. Abdullah, 2005. Prediction of soil and nutrient losses in a Highland Catchment. Water, Air Soil Poll., 5: 103-113. DOI: 10.1007/s1 1267-005-7406-X

Heathcote, I.W., 1998. Integrated Watershed Management: Principles and Practice. 1st Edn., John Wiley and Sons, New York, ISBN-10: 0471183385 , pp: 414.

IRI, 2003. Initial national communication to United Nations Framework Convention on Climate Change (UNFCCC). Islamic Republic of Iran.

Milani, P.M., J. Ghaderi and M. Kalhor, 2006. Nutrients Flow in Karkheh River Basin (KRB), Agricultre and Natural Resources Research Center of Kermanshah, Iran.

Najafi, B. and A. Shooshtarian, 2007. Estimating poverty line and investigating determinants of poverty for rural and urban households in Iran. Agric. Econ. Iranian J., 59: 20-32.

Nesbitt, T.J. and D. Weiner 2001. Conflicting environmental imaginaries and the politics of nature in Central Appalachia. Geoforum, 32: 333-349. DOI: 10.1016/S0016-7185(00)00047-6

Newton, A.C., 2007. Biodiversity Loss and Conservation in Fragmented Forest Landscape. 1st Edn., CABI Press, Wallingford, ISBN-10: 1845932625, pp: 416.

Nosyrov, M., 2004. Karnab Chul, Samarkand, Uzbahistan: Framework of assessment methodology. Proceedings of the 2nd International Workshop of Combating Desertification; Sustainable Management of Marginal Dry-lands, (CDSMMD' 04) UNESCO-MAB drylands, Shiraz, Iran, pp: 100-112. 
Pretty, J. and P. Shah, 2008. Sustainable Agriculture and Food. Earthscan Press.

Rafati, M., M. Farhad, A Nemati, M. Gheitouri and M. Rahmati et al., 2009. Status and Dynamics of Livelihood in Rural Households in Karkheh River Basin, Iran (Merek and Honam regions). International Center for Agricultural Research in the Dry Areas (ICARDA) and Agricultural Research and Education Organization (AREO), Iran.

Salem, B., 2004. Omayed biosphere reserve and its Hinterland, Egypt. University of Alexandria.

Shahmoradi, A., M. Ghaitori, S. Ahmadi and A. Tavakoli, 2008. Vegetation assessment and participatory development of techniques for rehabilitation and sustainable management of rangelands and forest ecosystems of upper Karkheh River Basin. Agriculture Research and Education Organization (Iran) and ICARDA reports.

Sherwood, S.C., C.L. Meyer, R.J. Allen and H.A. Titchner, 2008. Robust tropospheric warming revealed by iteratively homogenized radiosonde data. J. Climate, 21: 5336-5352. DOI: 10.1175/2008JCLI2320.1

Silveira, M.L., N.B. Comerford, K.R. Reddy, J. Prenger and W.F. DeBusk, 2009. Soil properties as indicators of disturbance in forest ecosystems of Georgia, USA. Ecol. Indicators, 9: 740-747. DOI: 10.1016/j.ecolind.2008.09.006
Thomas, S., 2004. Overview of Sustainable Management of Marginal Dry-lands (SUMAMAD) Projects, UNESCO. Proceedings of the 2nd International Workshop of Combating Desertification; Sustainable Management of Marginal Dry-lands, (CDSMMD' 04), UNESCO-MAB dry-lands, Shiraz, Iran, pp: 5-7.

Titi, A.E., 2003. Soil Tillage in Agro-Ecosystems. 1st Edn., CRC Press, Boca Raton, ISBN-10: 0849312280, pp: 384.

Turkelboom, F., 2003. An integrated natural resources management (INRM) framework for copping with land degradation in dry areas. International Center for Agricultural Research in the Dry Areas (ICARDA), Aleppo, Syria. United Nation Development Program, 2009, Human Development Report 2009: Iran (Islamic Republic of Iran) The Human Development Index.

WB, 2005. Islamic Republic of Iran: Cost Assessment of Environmental Degradation; Rural Development. Published by Water and Environment Department; Report No. 32043-IR.

Yang, S., H. He, S. Lu, D. Chen and J. Zhu, 2008. Quantification of crop residue burning in the field and its influence on ambient air quality in Suqian, China. Atmospheric Environ., 42: 1961-1969. DOI: 10.1016/j.atmosenv.2007.12.007 